\title{
Insulting in English and Iraqi-Arabic: A Pragmatic Study
}

\author{
Zainab Kadim Igaab ${ }^{1}$ \\ ${ }^{1}$ University of Thi-Qar, College of Education for Humanities, Department of English, Iraq \\ Correspondence: Zainab Kadim Igaab, University of Thi-Qar, College of Education for Humanities, Department \\ of English, Iraq.
}

Received: October 10, 2021

Accepted: November 16, 2021

Online Published: November 22, 2021

doi:10.5539/ells.v12n1p24

URL: https://doi.org/10.5539/ells.v12n1p24

\begin{abstract}
Crimes are committed by uttering words or expressions, writing or signifying in a public way like insulting which is one of the crimes against public welfare. This crime has been dealt with and compared legally but its linguistic aspect has not been given much attention. This study tries to emphasize this crime pragmatically and contrastively in English and Arabic. No study has shed light on such aspects concerning the study under investigation. The researcher has not found any previous related study to get a benefit from about this topic. The aim of this study is to shed light on the points of similarity and difference in strategies of insulting in terms of speech act, implicature and impoliteness theories between English and Arabic. The present study hypothesizes the following: In terms of the three theories mentioned above, English and Arabic have points of similarities in strategies of insulting. To support or refute the hypothesis of the study, data consisting of 20 complaints in English and Arabic were collected from Courts of Appeal in Iraq, Britain and the United States. They are analyzed in terms of an eclectic model. The results arrived at are: English and Arabic are different in insulting in terms of the locutionary acts and illocutionary acts. Concerning impoliteness, the same strategies are applied to insulting in both languages. As far as implicature is concerned, the two languages are different in insulting.
\end{abstract}

Keywords: Arabic, English, insulting, pragmatics

\section{Introduction}

Insulting is a remark or an action that is said or done in order to offend somebody (Hornby, 2005, p. 675). It is considered one of the offences which negatively affect the person's freedom (A'tiya, 2010).

\subsection{Research Questions}

In strategies of insulting, in terms of speech act, implicature and impoliteness theories, what are the points of similarity and difference between English and Arabic?

\subsection{Aims of the Study}

Explaining to what extent English and Arabic are different or similar to each other in terms of the three theories mentioned above.

\subsection{Hypothesis of the Study}

In terms of speech act, implicature and impoliteness theories, English and Arabic have points of similarities in strategies of insulting.

\subsection{Data Collection Procedure}

The data of this study are a number of complaints which is 20. The English data are taken from the English website: https://www.govinfo.gov/ while the Arabic data are taken from judges of investigation in Nasiriya Court of Appeal and investigators in the police centre in Thi-Qar Province. The translation of the pragmatic and forensic linguistic terms into Arabic is taken from Ritchard et al. (2007). Longman Dictionary of Language Teaching \& Applied Linguistics: English-English-Arabic and Yousif (2020). "Conversational Maxims in Pragmatics".

\subsection{Procedure}

The procedure adopted to achieve the aims of the study and test its hypotheses includes the following:

1) writing the literature review of insulting from legal and pragmatic aspects; 
2) analyzing the English and Arabic data according to an eclectic model which consists of Grice's theory of implicature (1967); speech acts theory by Searle (1975); impoliteness by Culpeper (1999, 2005).

3) discussing the data whether English or Arabic;

4) writing the examples in the Arabic section follows two steps which are: a) translating the examples into English and b) transliterating it. The Arabic examples and the information are translated depending on a number of dictionaries listed in the references below in addition to the researcher herself; and

5) arriving at a number of general conclusions with showing the similarities and differences between English and Arabic in terms of insulting.

\section{Literature Review}

\subsection{The Legal Aspect of Insulting}

Insulting is one of the crimes against public welfare. It cannot be considered as a crime for any person except an official at the institute to do his/her job or because of doing the job; an official who is responsible for public welfare; an official in the judicial and administrative courts; or members in an assembly through holding a session. No definition is given by the Iraqi legislator but philology defines it as an attack against the official's honour, dignity and respect. Insult is expressed by uttering words or expressions, or signals to scorn the official and harm his/her prestige among the people (Betti, 2019, p. 184; Ahmed, 2013, p. 3).

This crime consists of two elements:

\section{a. Actus Reus}

A defendant makes insulting signals among the people against that official, or a number of words and expressions are uttered which include an insult, or a threat which contains warning that will harm the official's feelings. Every threat is an insult but not every insult is a threat. Insulting the official must be through doing the job, because of the job, following the job immediately but not preceding it (Ahmed, 2013, p. 4).

\section{b. Mens Rea}

Insulting is a deliberate crime which is fulfilled with existence of the intention and knowledge of the defendant. The defendant intends to behave in a way to insult the official and he/she must know all the aspects of the crime (Ahmed, 2013, pp. 4-6; Al-Qulaly, 1948, pp. 134-135).

But the amendment of the Public Order Act (1986), Section 5 (POA 1986) by the Crime and Courts Act (2003), Section 57 in January 2014 resulted a heated public debate on the "legality of insults in England and Wales. In May 2012, the campaign "Reform, Section 5: Feel Free to Insult Me" was launched and supported by a number of groups. According to their claims, such an act (1986) has a restriction on the citizens' right to speak free in addition to its negative effect on democracy (Schneider \& Zielasko, 2015, p. 187). There should be a number of conditions under which insulting behaviour is generally subject to criminal prosecution. POA 1986, Section 5 before the recent amendment:

"5 Harassment, alarm or distress. (1) A person is guilty of an offense if he (a) uses threatening, abusive or insulting words or behaviour, or disorderly behaviour (b) displays any writing, sign or other visible representation which is threatening, abusive or insulting, within the hearing or sight of a person likely to be caused harassment, alarm or distress thereby. [...]" (Schneider \& Zielasko, 2015, p. 188). That act was also supported by the European Charter of Human Rights in its Article 10 which emphasized the protection of the freedom of speech (ibid, p. 190).

Following the reform campaigners, insulting behaviour should only be legal if it is committed with no intention of harassment, alarm or distress. Under Bousfield's terminology, only actual impoliteness should be punishable (Under Section $4 \mathrm{~A}$ ) and rudeness which is mistaken for impoliteness should only be punishable (Under Section 5) if its intensity qualifies it as abusive behaviour (Schneider \& Zielasko, 2015, p. 193).

The British government wants to retain the word 'insulting' within Section 5 at least for the sake of minorities and religious groups who are the victims of verbal abuse. Section 5 is of a benefit because it includes boundaries of the conduct in which it is right or wrong. With this reform, ambiguity is created. Let the court judge the case whether it is abusive or insulting although insulting is of lower intensity than abusive. Examples of insulting are the swearing at others or the burning of remembrance poppies (ibid).

How can a person insult the chiefs or elders of the community? This is an affront to their authority and dignity. No community or law accepts ridicule or contempt (Elias, 2014, p. 66). Every law does not encourage all anti-social acts or omissions which push public functionaries and law-abiding individuals into hatred, ridicule or 
contempt. Anyone should show respect to the court and not disturb its proceedings (Elias, 2014, p. 69).

Different interpretations of the term 'insult' in relation to 'abuse' are put by the legal contexts. According to Culpeper (2011, pp. 77-78), verbal abuse acts as a frequent metalinguistic label for impoliteness. Oxford English Dictionary (2010) finds it difficult to make a semantic difference between insult and abuse. Both can define each other. "To insult" is to treat someone with scornful abuse or offensive disrespect"; "to abuse" is to speak insultingly or unkindly of or to". But according to Longman Dictionary of Contemporary English (2009), "abusive" is the use of the cruel words. The meaning of abuse and insult is equal: to say rude or offensive things to someone is to insult.

To other dictionaries like Merriam-Webster (2003), abuse and insult are different in meaning. Insult is defined as a rude or an offensive behaviour or showing lack of respect but abuse is "to attack in words, unjustly condemn or vilify", or abuse as "using harsh insulting language. In a wide range of contexts, insult and abuse are synonyms but the usage data from a corpus analysis indicates that abuse does not readily cover low intensity of offensive behaviour (Schneider \& Zeilocks, 2015, pp. 199-201).

\subsection{The Pragmatic Aspect of Insulting}

Insulting is fulfilled by uttering words or expressions which hurt an official's honour and consideration, threatening an official during doing the duty in his job. Insulting is any saying or doing regarded by the community and its traditions scornful and hurting the dignity in his habitants' eyes. It is not necessary that those words or expressions carry abusive or defamatory meanings but in so far as they hurt an official's feelings, dignity, esteem, they are described as being insulting.

Law punishes anyone who attacks the officials during doing their duties because they are under its protection. No measure determines that this word or gesture is insulting or abusive; it depends on the scenario or situation. But there are terms which have no function than to belittle, scorn, or put down someone's honour, esteem, dignity, like "nigger". Abusive or insulting terms should be looked for among people out the houses because within the families, their members are used to exchange some terms which are socially forbidden among people. In the same community where people socially interact with each other, there is no published list to rely on, but any citizen of a particular community can discriminate an insulting expression from one which is not an insulting one. And this idea is not true if we take some factors like education, social class, and profession into account. For example, when a teacher becomes among uneducated people who are working differently, he cannot discriminate their words or expressions as insulting or non-insulting. But when that teacher lives among other teachers, he/she will know what is said is insulting or not. There is no systematic framework within which an insulting term is constituted. So, insulting words or expressions are not universal. Every group in the same community has its own specific look for insulting which has its severely negative opinions against a person or a group. Subverting someone's self-esteem may cause troubles for persons. When you insult someone, you will hurt his feelings and the result will be a negative reaction against the latter. What counts as an insulting or abusive word or expression is different from one language to another, from one culture to another. Even within the same language, different views are to consider certain terms insulting or abusive (Ahmed, 2013, pp. 2-13).

\subsubsection{Interpretation}

In the example,

- You're an idiot, Mark you've scared him off.

The use of the word 'idiot' is to describe a person as foolish or senseless. This has highly offensive overtones (Piskorska, 2017, p. 63).

In general, there is no correspondence between the interpretation and perlocutionary effects of an utterance and the literal meaning of the words that are used. Instead, the meaning and the force of an utterance result from the interaction between what is literally expressed and the context of use. The utterance of a novelty offensive content and the use of the derogatory words may not be the reason for an offence or it may be to a limited extent. In some cases, utterances without overtly offensive terms, they are used to refer to betting criticism at the level of implicated content. An attention is paid for the appropriate use of insults. Such uses include meaning reversal, or normative reversal, where words which are conventionally considered as insults are used as indicators of belonging to the same group or community. The speaker and the hearer are able to afford to use offensive words or expressions addressed to each other since they share enough contextual assumptions and common ground to override general linguistic conventions. 


\subsubsection{Speech Act of Insulting}

According to Peccei (1999, p. 43), when an utterance is contextualized, it does far more than simply asserting. That does not mean that such an utterance does not include an assertion, but it involves a more basic purpose behind it. For example,

- You have been offended and want revenge.

"Insulting" is clearly looked at as a sign of fractures or fissures in social and political civility which makes a rise to turmoil and conflict. A wealth of literature is devoted to "conflict management" in both business settings and international diplomacy (Conley, 2010, p. 2). In English, the synonyms for "insult" are "slighting, affront, ridicule, malediction, vituperation, invective, contumely, mocking" or at a more vernacular level, "naming-calling, roasting, put-down" (ibid, p. 3).

In the polite research, there is an explanation of the interpersonal mechanics of insults and other kinds of impolite behaviour. According to Brown and Levinson (1987, pp. 61, 66), insults are considered as a threat to a person's positive social face, that is, "the positive consistent self-image claimed by interactants". It is complemented by the negative face as "freedom from imposition".

Insulting is both illocutionary and perlocutionary acts. A person who insults an official in any institute harms his dignity and lowers his personality and pride among his colleagues. That official will work without any confidence and he will be nothing in front of the people in his community.

\section{The Model of the Study}

The model of the study is eclectic, i.e., it is taken from Grice (1967), Searle (1975), Culpeper (1996, 2005). An eclectic model is used to analyse and discuss the verbal offence which is insulting.

Following the model, English and Iraqi-Arabic cases will be analysed. Implicature and impoliteness are the same in both languages while speech act theory is different from English into Arabic. With Speech act theory in Arabic, there are different points of view and opinions presented by Arab linguists, grammarians, and rhetoricians. But they agreed on the distinction made among locutionary, illocutionary and perlocutionary acts. So, cases of both languages will be analysed following the same model by Searle (1975).

\subsection{Implicature}

In 1967, Grice first presented his theory of implicature. In his theory, he tried to elucidate how the hearer gets from what is said to what is meant; from the level of the expressed meaning to the level of the implied meaning (Grice, 1975, pp. 43-44).

\subsection{Impoliteness}

A great attention has been paid to politeness and a little attention to impoliteness. Impoliteness which is described as being a poor cousin of politeness has been neglected (Locher \& Bousfield, 2008, pp. 1-2).

According to Bousfield and Culpeper, understanding the speaker's intentions by the hearer is the key for impoliteness while to Terkourafi, it is the rudeness rather than impoliteness. The fourth definition was presented by Locher and Watts. It is a negatively marked behaviour which has violated the social norms (Culpeper, 2011, pp. 19-20). The result is negative evaluations like 'impolite, over-polite, rude, aggressive, insulting, sarcastic, etc', relying on the degree of the violation and the kind of conceptualization (Locher \& Bousfield, 2008, pp. $3-4)$.

Impoliteness is a type of the perlocutionary effect. It includes the hearer thinking that the speaker is approaching/withdrawing inappropriately given cultural norms whether this involves omitting an appropriate move or adding an inappropriate one. The effect of constituting face is a threat to face. Impoliteness is distinguished by being a face-threatening perlocutionary effect (Terkourafi, 2008, pp. 60, 62).

Culpeper (1996) defined impoliteness as "the use of strategies designed to attack face, and thereby cause social conflict and disharmony." Then in 2005, Culpeper refined this definition into the following:

Impoliteness comes about when: (i) the speaker communicates face-attack intentionally, or (2) the hearer perceives and/or constructs behaviour as intentionally face-attacking, or a combination of (1) and (2).

In 2005, Culpeper suggested and developed a model where there is a shift in the focus of intentional, impolite face-attack away from a Brown and Levinson style 5-point model of offensive super-strategies. That model was proposed by Lachenicht (1983) and Culpeper (1996) and followed by others. The super-strategies are:

(1) Bald, on Record Impoliteness 
The speaker intends to attack the face of the hearer and/or where the speaker does not have the power to (safely) say an impolite utterance. The utterance is expressed directly, clearly, and unambiguously (in a full way in accordance with Grice's maxims, 1975).

\section{(2) Positive Impoliteness}

It is the attacking of the hearer's want to be approved of, which is clearly linked with Spencer-Oatey's (2002) quality face and elements of sociality face. It involves strategies used to damage the recipient's positive face wants. Instances of those strategies are 'ignore, snub the other, exclude the other from the activity, dissociate from the other, be disinterested, unconcerned, unsympathetic, use of inappropriate identity markers, use obscure or secretive language, seek disagreement, make the other feel uncomfortable, for example, do not avoid silence, joke, or use small talk, use taboo words, call the other names, etc.' for example, 'shut up' which is regarded as an obstacle of.

\section{(3) Negative Impoliteness}

Culpeper makes a link between attacking your freedom of action and Spencer-Oatey's (2002) equity rights and then with association rights. It involves the use of strategies which damage the recipient's negative face wants. The examples of those strategies taken from Culpeper (1996) are 'frighten, condescend, scorn, or ridicule, invade the other's space, explicitly associate the other with a negative aspect, put the other's indebtedness on record, etc.'

\section{(4) Off-Record Impoliteness}

This super-strategy was introduced by Culpeper (2005) instead of the 'meta-strategic' nature of sarcasm. Here, the offence can be conveyed in a direct way in terms of implicature that could be cancelled. For example, threatening someone of beating him.

\section{(5) Withhold Politeness}

With the absence of politeness, impoliteness may exist. For example, a person does not thank the other for giving him a present.

Such a model has been re-explained since there is a problem with a bold, on record strategy because it is not found outside of the theorist's vacuum (Culpeper, 2013, p. 5).

\subsection{Identifying Speech Acts}

Language is not only used to say things (to make statements) but also to do things (perform actions). Such a conviction pushed J. L. Austin to make a theory of what he called "illocutionary acts", "speech acts", "illocutionary force", "pragmatic force", or "force". Things are done by words.

Speech act theory was first put forth by Austin (1962) and further developed by Searle $(1969,1979)$. This theory is based on two major ideas. The first is that the meaning of an utterance is distinct from the function performed by that utterance which is called the force; and the second is that all utterances amount to the execution of an act (Collavin, 2011, p. 373).

$$
\begin{gathered}
\text { Background } \\
\downarrow \\
\text { Speech Acts } \\
\downarrow \\
\text { Implicature } \\
\downarrow \\
\text { Impoliteness }
\end{gathered}
$$

Figure 1. An eclectic model for analysing insulting

\section{English Data: Analysis and Discussion}

Ten cases are selected and focused on for analysis under the eclectic model. Then this study is to rely on the results from their discussion.

1) a. Background 
Detectives from the Columbus Division of Police Vice Unit (PVC) were conducting an undercover operation related to the sale of liquor to minors at the Thirsty Whale. There was a complaint against the Thirsty Whale bar. They entered the bar to have alcoholic beverage for the evidentiary purpose.

\section{b. Speech Acts}

When the detectives wanted to get information from the bartender, the plaintiff, Underwood, started yelling "damn the police, "damn you," "what can they do," "there are only two of them." Underwood was accused of insulting the police officers because of obstructing official business in violations of Columbus city code.

Underwood intended to affect the people's sentiment against the police.

After making them too angry and nervous, Underwood said in front of the others "I am not resisting," when he was arrested, but one of the police officers placed the muzzle of his gun against the backside of Underwood's head and stated, "I could blow your damning brains out and no one would give a shit about it." The purpose beyond all those unlawful actions were to impede the public official in the performance of the public official's lawful duties.

Then he tried to threaten them indirectly by saying loudly and pointing out at the police officers, "what can they do", "there are only two of them". The locutionary acts are sentences which are either declarative or interrogative, positive or negative.

2) a. Background

Plaintiff, Cotton, an African American working for Defendant ST. Louis Public Schools in 2008, was terminated in her work because of race discrimination in 2011.

b. Speech Acts

All the persons within the jurisdiction of the United States have the same right to make and enforce contracts as is enjoyed by white citizens.

Although the white male employees are with less seniority, they are not terminated in comparison with the black ones.

"You do not deserve to live." "It is difficult to work with you because you are nigger and jig." "You are working as if you are a buffalo."

All those terms of racial abuse and insulting utterances make her feel embarrassed, desperate and socially less than the others.

\section{3) a. Background}

The plaintiff, Parker, an African- American, had a management position in labour relations with the United States Postal Service (USPS) and therefore, she was not eligible to join a union. In a meeting, the representatives of the National Association of Letter Carriers created a hostile environment against Parker that the USPS allowed to occur. They disparaged her competence and attempted to convince the USPS to remove her. So, they were against the civil rights because of race discrimination.

\section{b. Speech Acts}

The representatives refer to that meeting as a 'lynching' and they call Parker and other African-American managers 'illiterate monkeys', 'useless', 'incompetent' and 'unqualified'. They also express "hope that an African-American manager die because he was undeserving of respect."

The locutionary act is expressed by a noun phrase, a sentence and an adjective. The illocutionary act is insulting her. This is a negative effect on her in the job. As a result, they narrow her job responsibilities and deny her opportunities for promotions. She is the victim of workplace bullying.

4) a. Background

Marshall alleged "I am treated disrespectfully and unfairly at the work place due to the fact that I am an AfricanAmerican black female, of non- Carribean island ancestry". She complained "I am the only African-American employee at the Alley E Toll Plaza staffed by my co-workers and supervisors, all of Carribean island ancestry, shunned and disrespected me because I am African-American and I am unable to speak a Carribean language." She alleged "my manager threatened me to demote me to a night shift or transfer her to another toll plaza in retaliation for my complaints about Aretha." One of her supervisors said, "She did things like a nigger", "Going home to Africa," "She is coon".

b. Speech Acts 
There are two illocutionary verbs which are 'allege and complain'. As an insult, they threaten her more than one time to affect her negatively. They make her feel that she is nothing and she has to go back home which is Africa She is not guilty but she is African-American. That is her only guilt.

\section{5) a. Background}

Gomez is of the Native American heritage. He contended "after I filed an inmate grievance a policy change was ordered by Warden Gipson limiting his religious ceremonies to once a month without a spiritual advisor." A Committee resource manager refused to treat the Native with the same respect and rights afforded to other religions, like Catholics, Protestants and Islamic religions as those religions are allowed weekly ceremonies. So, those who were of Native American heritage were treated rudely and disrespectfully in comparison with the others.

\section{b. Speech Acts}

One of the officers use racist remarks that are offensive by calling Plaintiff "Chief" and "Cowboy." Words which are noun phrases are used to insult Gomez for racist reasons. Because he was hurt in terms of his job and feelings, he filed a complaint against those committee officers.

6) a. Background

Plaintiff asserted "I am a professor at California University and has been subjected to harassment and retaliation based upon my race and national origin. There are violations for my title and rights."

\section{b. Speech Acts}

He contended "California University denied my promotion to full professor and salary increase and failed to properly evaluate my contributions in the areas of teaching, service to the university and community and in research and scholarship." Most instructors and officers at the university told me "You do not have any right in our country because you do not belong to us. You are not included in our protected class. You are nothing. You are spear." Insulting the professor is achieved by a number of expressions which is an obstacle in his promotion and the increase in his salary not like his colleagues. Thus, he feels different from the others by being lower than them socially to make him lower scientifically and academically.

7) a. Background

Similarly, because of race-based employment discrimination, Ruby, an African American, who was hired by a department of human assistance of Northern California as an on - call site coordinator, was deprived of promotional opportunities.

\section{b. Speech Acts}

Ruby is described by them as being 'jungle bunny and night fighter'. She alleged "they embarrassed me and I was feeling depressed and exhausted." The way of insulting her as an employer is using words, which affects her negatively. Their purpose is to destroy her psychologically to leave her work and back home.

8) a. Background

In a prison, Adams wanted to sue a jail guard and the guard's helper for mistreating him and insulting him.

b. Speech Acts

Adams alleged "during my lockup, I was yelled at and told to shut up many times. I was forced to wear a blue suit when they said I was suicidal." Adding "I was hit from behind and I was told that I had to do what I was told and respect workers." By using those sentences to insult him among the others causes him an emotional breakdown.

\section{9) a. Background}

Archie, a civil detainee in the custody of the California department of Mental Health at a hospital, was deprived of his rights. A civil detainee retained greater liberty protections than individuals detained under criminal process and he was entitled to more considerate treatment and conditions of confinement than criminals whose conditions of confinement were designed to punish.

\section{b. Speech Acts}

He alleged "O'Brian insulted me and gave my meal to another patient and I was subjected to excessive force." O'Brian said, "I am stupid and do not know how to speak or behave as if I am an idiot. I am like a monkey who is jumping here and there. This made all fun of me." "This made me hate life and myself. His conduct caused me to fear a possible altercation with another inmate in which Plaintiff would be injured". Full sentences were used 
for insulting that person.

10) a. Background

Steven, an employee of the Defendant American airlines, Inc. alleged "the defendant discriminated against me due to a perceived mental disability and fostered a hostile work environment on the basis of that perceived mental disability as they said."

b. Speech Acts

His co-workers believed "the plaintiff had illegally brought her pet rat on board an international flight." They also added "Steven carried pet rats in his pocket onto work flights." Steven alleged "the two co-workers were under the false perception." Thinking and saying those things in this way are to insult Steven. Such an action severely traumatizes Steven and causes him to suffer from symptoms of post-traumatic stress disorder, which negatively affectes his ability to perform certain job functions.

c. Implicature

In the insulting cases, implicature does not exist.

d. Impoliteness

Culpeper's model is prominent because it is examined through different discourses and it is practical for the data of real life (Bousfield, 2008b).

For insulting persons, negative impoliteness with two subcategories is used. They are 'condescending, scorning or ridiculing. The speaker emphasizes your relative power. The speaker is contemptuous', for example, The use of abusive words like 'nigger, jig, buffalo, illiterate monkeys, useless, incompetent and unqualified coon, chief, cowboy, spear, jungle bunny and night fighter, stupid, like a monkey which is moving here and there.

The second subcategory is 'explicitly associating the other with a negative aspect. The speaker personalizes using the pronouns 'I' and 'you', for example, damn the police; damn you; you do not deserve to live; you do not have any right in our country because you do not belong to us; you are not included in our protected class. you are nothing.

There is a use of some expressions like 'carrying pet rats in his pocket onto work flights'.

The use of noun phrases, adjectives, full sentences is to condescend, scorn, ridicule the others. It is also to belittle them.

\section{Arabic Data: Analysis and Discussion}

An insult is any word or expression which hurts an official's feelings, dignity or consideration or accusing $\mathrm{him} / \mathrm{her}$ of a certain wrong act. It is not necessary for that word or expression to refer to verbal abuse or defamation. So, insulting as a verbal offence is to be discussed and analysed in terms of an eclectic model.

1) a. Background

A policeman was in a police inspection to search a lady who was booked at a woman's home. That policeman accompanied by one of the lawyers and an old man in the same area asked that woman to open the door for the search.

b. Speech Acts

The woman refused to open the door and told him:

"No one even the police can enter and take me to the police office, it is better for you to go."

(lalshurTa wala ?inta walal?aHsan minek yegdar yaxDny liqism ?alshurTa. ?aHsanlek truH minhina.)

Although this speech does not have any word of verbal abuse or defamation, it includes something of contempt and it hurts an official during a period of doing his duty.

2) a. Background

A committee from Ministry of Agriculture visited one of its offices to review the files.

b. Speech Acts

One of the committee members asked the accused about some documents and information concerning that office, the latter said:

"Who are you to ask me about these things or you ask me to listen to you? You are nothing and this is not within your business." 
(minu ?inta wshinu Sifetek tuTlub minni hay ?il?ashyaa? ?aw ?asma9lak. ?inta la shay? wala haDa ?ilshi yxuSek.)

That official is under his duty and the accused says some words and expressions which touch his dignity among other officials. The purpose beyond such an act is to put an obstacle in the committee member's work.

3) a. Background

When a judge issued an order of putting the accused in a prison, the latter said with yelling in front of the others inside the court,

"For the sake of that judge you prisoned me, this is injustice and unacceptable by Allah and people."

(lxaTir haDa ?ilqaDhi txaluny bilsichin hatha Dhulum la ?allah yqibla wala ?ilnas.)

b. Speech Acts

The words which are said by the accused against the judge include a reference to accuse that man of law of being unfair and he does not give the accused his right. This is the way how to scorn a man of law by a criminal.

4) a. Background

A manager at Bint-Al-Huda hospital for getting birth and children, Dr. Rashid filed a complaint against three pharmacists who were talking with others against him,

"Let's publish Rashid's chats in Panadol group," "he is directly against the pharmacists in a disgusting way," "let's inform the Minister of Health of that topic," "put Rashid's photo in the post."

(xeli ninshir swalif rashid 9ala gruub panadol. mustahdif ?ilSayadila bishikil bashi9. xeli nwaSil ?ilmawDhuu9 lilwaziir. txaluun Surat rashid bilpost.)

b. Speech Acts

As a manager of the biggest hospital in Nasiriya, his officials are talking in such a funny way, using unfair accusations to defame him and threaten him in a direct way. Putting the manager's photo on the post is the way to focus him in front of the Minister and the others. It is to expose him to devalue him among his students and patients. This hurts his self honour and consideration.

5) a. Background

A member of the city council saw two young people washing their car in the middle of the street with making it full of water. Thus, it was difficult to cross the street because of the water and the cars.

\section{b. Speech Acts}

The member of the city council asked the two young people about the reason beyond doing this and asked them to leave this place but they answered him,

"As we like and if you talk more we will insult you," "What are you doing here? This is not your business, go and sit on your chair as a doll."

(bkifna wa?iDa tiHt3i nhinek. ?inta shinu hatha mu shuGlek ruuH w-?ig9id 9ala kursiyak mithil ?ila9aba.)

Such utterances are uttered by those two men in the middle of the street, which hurt the member's dignity and consideration among his inhabitants. They become as an obstacle in doing the duty. They are deliberately behaving in this way to continue doing the wrong.

6) a. Background

A student's father went to a school to ask about his daughter's scientific level. The manager of the school told him that his daughter was so lazy and she was absent in most days, so the manager wanted his daughter to exert her efforts.

\section{b. Speech Acts}

The father answered the manager,

"I insult you and your tribe."

(?ahinit3 w- ?ahiin 9ashirtit3.)

The father insults the manager among all the teachers, which hurts her educational honour, consideration and her job as a teacher. So, this is an insult for the education in general. This is only to force her to avoid his daughter's faults. 


\section{7) a. Background}

An official at an office at the Ministry of Trade found a car stopping in front of the office main door. She asked the car driver to be away from the door where the officials and employees pass.

b. Speech Acts

The driver shouted and said,

"You do not feel shy and no one can control you. You are without characteristics."

(ma tistiHiin wma?ilit3 raddad w? inti biduun ?axlaq.)

It is shameful for a man to talk with a woman in such a way. She feels so embarrassed because the driver harms her honour and dignity.

8) a. Background

A teacher filed a complaint against one of the students' parents because the student's father insulted him.

b. Speech Acts

The father said,

"My son did not succeed because he did not give you a bribe. Without bribes, you do not know how to work. We felt bored of you."

(?ibni ma nicheH li?an ma difa9 rashwa. ?intu biduun rashawi ma t9irfuun tishteGluun. mu mellina minkum.)

In this case, the teacher is accused of being a briber. So, the teacher is clearly insulted when he is doing his duty inside the school. The father expresses his negative feelings towards the teacher only because the teacher told the father the truth about his son's true schietific level. The father gives his son's failure a justification that the teachaer does not make the students pass the year without paying for the teachers bribes.

9). a. Background

A patient went to the hospital to examine himself, the doctor told him he needed an operation for his heart otherwise he would die.

b. Speech Acts

The patient replied the doctor,

"Doctor, you do not know to give patients medicine, how you can examine his illness."

(dictor ?inta ma tu9ruf tinTi 9ilach lilmariiDh shlon tu9ruf tshexiS maraDhah.)

Such an utterance is said inside the hospital. That patient hurts all the doctors' feelings, consideration and professional honour. Because of the patient's feeling of astonishment, worry and fear due to the operation, a doctor with years of knowledge, science, experience and exerting of efforts for the patients is insulted because of a patient instead of being thanked for.

10) a. Background

A number of persons went to the Electricity Department in Nasiriya. The official told them there was an equal portion for all areas of Thi-Qar province.

b. Speech Acts

One person inside the department said loudly,

"You are coward; you do not fear us because we are normal people not rich." "Come here out of your office and I'll show you the courage itself."

(xayib yalimxannath ?intu ma tgidruun bas 9alfuqra ?illi mithilna. ta9al hna wa?rawiik ?ilsiba9iyya shinu shakilha.)

Using such a word and expressions inside the office towards an official who is working for serving the people of the city is an insult, which hurts every official's consideration and honour. People should thank the officials in the office for doing their duties towards their home not insult them to be lowered among their colleagues.

c. Implicature

In the above ten cases, implicature does not exist.

d. Impoliteness 
The speaker uses negative impoliteness with two subcategories to insult the officials. The subcategories are 'condescending, scorning or ridiculing. The speaker emphasizes your relative power. The speaker is contemptuous'.

Using an abusive word; expressions or utterances is to condescend the official during his hours of work. In the institutes, the officials should be thanked and respected under the protection of the government not to be insulted and lowered.

The second subcategory is 'explicitly associating the other with a negative aspect. The speaker personalizes using the pronouns 'I' and 'you', for example,

One of the subcategories of impoliteness is using the following pronouns which are: you (?inta), (kaf), (chiim), (?inti), (?intu), (na) which are available in the above ten cases.

The words, expressions or utterances are sometimes mixed with threatening.

Accusing a man of law inside the police centre is an insult; or accusing a doctor of treating the officials badly inside the hospital is also an insult.

\section{Conclusions}

There are a number of conclusions which are arrived at through this study. These conclusions are illustrated by the following general conclusions, similarities and differences in insulting between English and Arabic:

\subsection{General Conclusions}

1) By using threatening, insulting or abusive words or expressions publically or non-publically, a person is guilty of an offence according to the Iraqi penal code while in the criminal code for England, by using threatening, insulting or abusive words or expressions publically, a person is guilty of an offence but if those words are heard by a person or persons inside a dwelling, otherwise the person is not guilty.

2) In everyday communication, understanding any utterance relies on the conventional symbols used by speakers to communicate and our knowledge we have about speakers and the situation where an utterance is made. So, by knowledge, the speaker's intention to convey is to be revealed.

3) The interpretation of insults is different from one community into another and from one person into another.

4) If there is no perlocutionary act, there is no verbal offence. The perlocutionary act is the characteristic feature of the verbal offence.

\subsection{Specific Conclusions}

These conclusions include a number of similarities and differences.

\subsubsection{Similarities}

1) Concerning the term 'pragmatics', there is a correspondence between English and Arabic. The Western scientists' efforts and the ancient Arabs' are complementary in terms of the study of pragmatics.

2) English and Arabic are similar to each other in terms of the legal language and its features.

3) English and Arabic agree on the locutionary, illocutionary, and perolcutionary acts. The same is with direct and indirect speech acts. But they are different from each other in terms of the way of classifying speech acts.

4) Insulting as a speech act has both illocutionary and perlocutionary acts.

5) Negative impoliteness exists in insulting. This point supports the hypothesis of the study in which both languages are similar to each other in insulting.

6) In English and Arabic, no implicature is available in insulting cases.

7) Insulting or verbal abuse are prohibited in both English and Iraqi-Arabic communities.

\subsubsection{Differences}

1) In Arabic, defamation, insult and verbal abuse belong to the same type but they are independent crimes from each other. In English, threat, insult and abuse are altogether included in more than one legal clause of the Criminal Code for England by the Law Commission No. 177 (1989).

2) In both languages, insulting is done for the officials at their departments or institutes but in English (British and American) communities, most insulting cases are done because of race discrimination and religion. Many insults are not paid attention to by people because of speech freedom. In Iraq, there are restrictions on the speech. Every person should be responsible for what he/she is saying. 
3) The linguistic way of expressing insulting in both languages is different. In English, to ridicule, condescend and scorn others is by using noun phrases, adjectives, the pronoun 'you' and then full sentences while in Arabic, it is done by using full sentences and a number of pronouns.

4) After presenting the points of similarity and difference above, the research question of this study isanswered.

\section{References}

Ahmed, G. (2013). Crimes of Insult, Defamation and Verbal Abuse: Commenting on them by Rules of Reversal of a Sentence and High Administrative Court. Cairo: Centre of Administrative Police Information.

Al-Qulaly, M. M. (1948). In the Criminal Responsibility. Cairo: University of the First Fuad.

Atiya, H. R. (2010). Criminal Protection for the Official: A Study in Egyptian and Libyan Legislations. Al-Mansoora: House of Thought and Law.

Betti, M. J. (2007). Jokes in Iraq: A Study of coherence and Cohesion. Journal of the College of Education, 1(1), 399-411. https://doi.org/10.31185/eduj.Vol1.Iss1.694

Betti, M. J. (2019). The Objective Penalty Protection of the Responsibles for the Educational and Learning Process. Unpublished MA thesis. Najaf: Al-Alamein Institute of Higher Studies.

Brown, P., \& Stephen, C. L. (1987). Politeness: Some Universals in Language Use. Cambridge: CUP. https://doi.org/10.1017/CBO9780511813085

Culpeper, J. (2011). Impoliteness: Using Language to Cause Offence. Cambridge: Cambridge University Press. https://doi.org/10.1017/CBO9780511975752

Culpeper, J. (2013). Impoliteness: Questions and Answers. In Aspects of Linguistic Impoliteness. https://doi.org/10.1075/hop.17.imp3

Elias, T. O. (2014). Insult as an Offence in African Customary Law. African Affairs, 53(210), 66-69. https://doi.org/10.1093/oxfordjournals.afraf.a094190

Grice, H. P. (1975). Logic and Conversation. Harvard: Harvard University Press.

Hornby, A. S. (2005). Oxford Advanced Learner's Dictionary of Current English (6th ed.). Oxford: OUP.

Locher, M. A., \& Derek, B. (2008). Introduction: Impoliteness and Power in Language. In Impoliteness in language: Studies on its Interplay with Power in Theory and Practice.

Longman. (2009). Longman Dictionary of Contemporary English (5th ed.). Harlow: Pearson.

Merriam-Webster. (2003). Merriam-Webster's Collegiate Dictionary (11th ed., Revised ed.). Springfield, Mass: Merriam-Webster.

Oxford. (2010). The Oxford English Dictionary (3rd ed.). Oxford: Oxford University Press.

Peccei, J. S. (1999). Pragmatics Language Workbooks. London: Taylor and Francis Routledge.

Piskorska, A. (2017). On the Strength of Explicit and Implicit Verbal Offences: A Relevance-Theoretic View. Cambridge: Cambridge University Library. https://doi.org/10.1515/9783110522976-003

Ritchard, J. C., John, P., \& Haydy, P. (2007). Longman Dictionary of Language Teaching \& Applied Linguistics: Emglish-English-Arabic (1st ed.). Longman: Egyptian International Publishing Co.

Schneider, K. P., \& Dirk, Z. (2015). When is an Insult a Crime? On Diverging Conceptualizations and Changing Legislation. University of Bonn.

Terkourafi, M. (2008). Toward a Unified Theory of Politeness, Impoliteness and Rudeness. In Impoliteness in Language: Studies on its Interplay with Power in Theory and Practice.

The Law Commission No. 177. (1989). Criminal Law: A Criminal Code for England and Wales (Vol. 1. Report and Draft Criminal Code Bill). London: Her Majesty's Stationery Office.

Yousif, B.-Z. (2020). Conversational Maxims in Pragmatics. Abhath Journal, 6(2), 110-124. 


\section{Appendix A}

\section{A List of the Symbols of Arabic Phonemes}

(Betti, 2007, pp. 409-410 with modifications added by the researcher)

\begin{tabular}{|c|c|c|}
\hline Arabic Phonemes & Example & Meaning \\
\hline$?$ & ?ams & Yesterday \\
\hline $\mathrm{b}$ & bab & Door \\
\hline $\mathrm{t}$ & timman & rice \\
\hline th & tha9lab & fox \\
\hline ch & chamaal & beauty \\
\hline $\mathrm{H}$ & Hariim & women \\
\hline $\mathrm{x}$ & xubuz & bread \\
\hline $\mathrm{d}$ & tdanna & Be nearby. \\
\hline $\mathrm{D}$ & Dabha & He threw it. \\
\hline $\mathrm{r}$ & ramul & sand \\
\hline $\mathrm{z}$ & zraar & button \\
\hline $\mathrm{s}$ & suug & market \\
\hline sh & shmaalak & What is wrong with you? \\
\hline S & Sabur & patience \\
\hline $\mathrm{Dh}$ & DhabuT & an officer \\
\hline $\mathrm{T}$ & TamaTa & tomato \\
\hline $\mathrm{Dh}$ & Dhaal & staying \\
\hline 9 & 9aali & High \\
\hline G & Graab & crow \\
\hline$f$ & fiil & an elephant \\
\hline q & qadiim & old \\
\hline $\mathrm{k}$ & ka9ak & cake \\
\hline 1 & limna & gather us. \\
\hline $\mathrm{m}$ & maxadda & pillow \\
\hline $\mathrm{n}$ & nibaH & Barked (The dog barked). \\
\hline $\mathrm{h}$ & hnaa & here \\
\hline $\mathrm{w}$ & warana & behind us \\
\hline $\mathrm{j}$ & yawm & day \\
\hline $\mathrm{g}$ & ga9ad & He set down. \\
\hline $\mathrm{p}$ & parda & Curtain \\
\hline t3 & t3aali & bank of the river \\
\hline i & mi9da & Stomach \\
\hline $\mathrm{a}$ & saliim & healthy \\
\hline $\mathrm{u}$ & ummii & My mother \\
\hline ii & biina & in us \\
\hline aa & saalim & Safe \\
\hline uu & 9uud & stick \\
\hline
\end{tabular}

\section{Copyrights}

Copyright for this article is retained by the author, with first publication rights granted to the journal.

This is an open-access article distributed under the terms and conditions of the Creative Commons Attribution license (http://creativecommons.org/licenses/by/4.0/). 